\title{
ALIEN FLORA IN THE LAKE ENGURE NATURE PARK
}

\author{
G̦ertrūde Gavrilova, Māris Laivin̦š, Agnese Priede, and Anda Medene
}

Institute of Biology, Miera iela 3, Salaspils LV-2169, LATVIA

E-mail: gga@email.lubi.edu.Iv

Communicated by Viesturs Melecis

\begin{abstract}
This paper describes the alien vascular plant flora in the Lake Engure Nature Park, one of the most species-richest and diverse areas in Latvia. The review was based on the floristic inventories conducted in 1983-1989 and a field survey carried out in 2010. In total, 68 alien species (7.6\% of the vascular plant flora in the nature park) were recorded, of which four had established in the period between both surveys. 22 species were recognised as adventive species and 46 as escaped species. Most of the alien species area concentrated in coastal villages, around human settlements, roadsides, coastal dunes and along streams discharging in the Lake Engure, thus mostly in transformed habitats. They are absent in most of the natural and semi-natural habitats. In comparison to the overall situation in Latvia, the Lake Engure Nature Park area is relatively little affected by plant invasions, most probably because large areas of natural and semi-natural habitats remain, since high naturalness of vegetation plays a significant role as a natural barrier hindering alien invasions.
\end{abstract}

Key words: alien flora, distribution, adventive species, escaped species, Engure.

\section{INTRODUCTION}

Lake Engure and its surroundings are well known as a significant migratory and nesting bird site (e.g., Transehe, 1937; Mihelsons, 1960; Vīksne, 1997). Besides the diverse bird fauna, at the end of the $20^{\text {th }}$ century, studies in the Lake Engure area indicated that it was also surprisingly rich in vascular plant species and communities (Pakalne, 1994; Gavrilova, 1999; Gavrilova and Baronina, 2000; Laime, 2000; Salmina, 2009).

Calculation of the species-area ratio in Latvia (Laiviņš and Gavrilova, 2009) indicates that the terrestrial part of the Lake Engure Nature Park $\left(128 \mathrm{~km}^{2}\right.$, except the adjacent marine area $71.9 \mathrm{~km}^{2}$ ) contains 220 more species than would be expected by the average number per $1 \mathrm{~km}^{2}$ in Latvia. This means that Lake Engure and its surroundings is a significant site of vascular plant diversity. In total it harbours 866 taxa of vascular plant species. Numerous species-rich plant families are well represented in the flora of Lake Engure Nature Park, e.g., the flora contains $76 \%$ of all Juncaceae species, $72 \%$ of all Orchidaceae species, $69 \%$ of all Cyperaceae species and 64\% of the Potamogetonaceae species, all of which are found in the relatively small territory of the nature park (Gavrilova and Baronina, 2000; Gavrilova u.c., 2005).

The littoral zone of Lake Engure and its surrounding fens is dominated by calciphiluous plant communities of alliances Magnocaricion elatae and Caricion davallianae, which belong to the associations Cladietum marisci, Schoenetum fer- rugineus and others with a large variety of sub-associations and variants.

Overall, the richness of vascular plant species and communities is associated with natural environmental conditions, particularly with humid and calcareous substrates. Also human impact over the $19^{\text {th }}$ to $20^{\text {th }}$ centuries have positively influenced the diversification of flora and vegetation in the Lake Engure area. The water table of Lake Engure was lowered in 1842 , thus creating about $45 \mathrm{~km}^{2}$ of land (Vikssne, 1997). This created a suitable habitat for numerous plant species and communities. Presently, about 160 years later, many plant communities in the former lake bottom, particularly forests communities, are in various successional stages, increasing species richness of the area. Regular grass cutting and grazing, especially in the $19^{\text {th }}$ century and the beginning of the $20^{\text {th }}$ century (Birzvalks, 1938; Vīksne, 1997) were also among the significant influencing factors promoting the diversification of flora and plant communities.

In the nature park, there is a well-pronounced dominance of native species that comprise $92.4 \%$ of all vascular plant species, while the alien species form only $7.6 \%$ (68 species) of the flora in the nature park. Overall, in Latvia alien plant species comprise about 33\% of the flora (Gavrilova and Šulcs, 1999; Priede, 2009b). Thus, the significant proportion of native species in the flora of the nature park indicates high naturalness and low human pressure on ecosystems. In the future, establishment and spread of new alien plant species might be expected, thus causing transforma- 
tion of the flora and environment. Therefore, it is necessary to understand the current composition and distribution patterns of alien flora and its relation to habitats in the nature park. This paper is targeted at identification and analysis of features of the alien flora in the nature park.

In this study, only neophytes (non-native species established in Latvia after the $18^{\text {th }}$ century) were recognised as aliens. The terminology used in this paper is derived from the widely used terms adventive species (unintentionally introduced species) and escaped species (garden escapees, species escaped from cultivation). This division is used also in the latest published checklist of the Latvian flora (Gavrilova and Šulcs, 1999).

\section{MATERIALS AND METHODS}

Study site. Lake Engure is the core of the nature park, and is the oldest protected and the most diverse part of the study area. The first status of a protected area was granted to the lake in 1957 with the total area $45.0 \mathrm{~km}^{2}$ (Linkaitis and Rits, 1972). Later, the borders of the protected nature area were extended several times, and in 1998 the lake and its surroundings became a nature park with a total area of $199.9 \mathrm{~km}^{2}$. Currently it is included in the lists of Natura 2000 and Ramsar sites (Kabucis et al., 2004).

The diversity of land use types in the nature park are well represented in the CORINE Land Cover 2006 data base (Anonymous, 2010). In the nature park, the relative area of open waters and wetlands is $66.8 \%$ of the total area. The largest part of this area falls into the aquatorium of the Gulf of Riga, with $36.4 \%$, and $12.9 \%$ in Lake Engure. Large areas $(17.5 \%)$ are covered by inland marshes and fens located along the shores of Lake Engure. 26.2\% of the area in the nature park is forested: $18.5 \%$ by coniferous forests and $7.7 \%$ by mixed forests. $5.3 \%$ of the area is scrubland, which surrounds the lake and occurs on abandoned agricultural land. Presently, the area utilised for agriculture (pastures, meadows, arable lands) is small and comprises $1.3 \%$. Dunes occur in only about $0.1 \%$ of the area, and urban land-use in about $0.4 \%$ of the total area of the nature park.

Flora inventory. Field inventory of the vascular plant flora in the Lake Engure Nature Park was conducted by G. Gavrilova in 1983 to 1989 . The territory was divided into a regular $0.5 \times 0.6 \mathrm{~km}$ grid (totally 594 grid squares); in each grid square all vascular plants were recorded. As a result, the checklist of the Lake Engure Nature Park (Gavrilova, 1999; Gavrilova and Baronina, 2000) and the Atlas of the Lake Engure Nature Park (Gavrilova et al., 2005) were compiled. In 2010, the vascular alien flora of the Lake Engure Nature Park and the Lake Engure drainage basin was surveyed by A. Priede. The species nomenclature follows Gavrilova and Šulcs (1999).

Classification of habitats. Habitat type(s) for each alien species were defined. Habitats found in the territory were divided into seven major groups and 26 sub-types according to their floristic and physiognomic features (Appendix 3). The habitat types were identified according to the hierarchically highest syntaxa in Latvia (class, order and alliance levels) (e.g., Laiviņš, 1998; Rūsiņa, 2007; Salmiṇa, 2009) and the principles of classification of habitats in Latvia and classification of protected habitats in the European Union (Auniņš et al., 2000; Kabucis, 2000; Auniņš, 2010).

Data analysis and mapping. Multi-variate analysis using Principal Component Analysis (PCA; McCune and Grace, 2002) was applied to determine the main gradients in composition of adventive and escaped specie communities in relation to habitat types.

A regular grid was used in mapping of species distributions,. The size of each grid unit was $0.5 \times 0.5 \mathrm{~km}$. Species distribution maps were created using ESRI ArcView 9.3 software. The visual design of maps was created by K. Sončika (Sončika, 2006).

\section{RESULTS}

Biogeography of alien plant species in the nature park. In total, 68 vascular alien plant species were recorded. According to their origin and pathways, they were divided into two groups: adventive species, which established and spread without intentional human assistance (22 species, Appendix 1), and escaped species - species escaped from cultivation (e.g., gardens, parks), established and spread without direct human assistance (46 species, Appendix 2).

Among the adventive species, species of the Asteraceae family (Galinsoga parviflora, Lepidotheca suaveolens, Conyza Canadensis and Carduus nutans) and Cruciferae family (Erucastrum gallicum, Diplotaxis muralis and Sisymbrium loeselii) predominate. In the group of escaped species, species of the Rosaceae family ( $18 \%$ of the total number of garden escapees): Amelanchier spicata, Aronia prunifolia, Crataegus alemanniensis var. alemanniensis, Malus domestica, Rosa acicularis, $R$. canina, $R$. rugosa and Fragaria moschata) prevail followed by Asteraceae (Artemisia absinthium, Aster salignus, Matricaria recutita, Solidago canadensis) and Leguminosae (Lupinus polyphyllos, Onobrychis viciifolia, Trifolium hybridum and Vicia sativa) families with $9 \%$ of all escaped species in each.

Most of adventive species (53\%) are cosmopolitan species with large distribution ranges. Acorus calamus, Elsholtzia ciliata, Galinsoga parviflora, G. quadriradiata and Juncus tenuis are cosmopolitan species with panzonal distribution, while Asperugo procumbens, Atriplex hortensis, Buglossoides arvensis, Lepidotheca suaveolens, Carduus nutans, Conyza canadensis, Epilobium adenocaulon and Epilobium rubescens have polyzonal Holarctic (meridional-boreal zone) distribution ranges.

Overall, the escaped species have smaller distribution ranges in the sense of zonal dimensions than adventive species. Among the escaped species, there are numerous spe- 


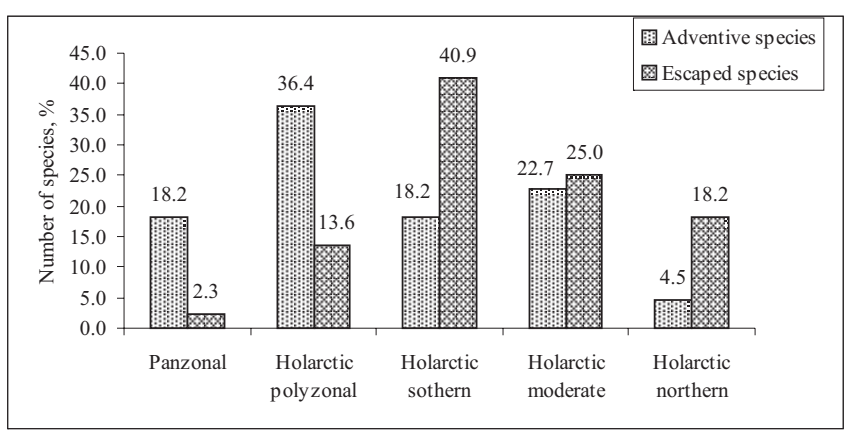

Fig. 1. Zonal distribution ranges of alien flora in the nature park

cies with Holarctic southern (meridional-temperate zone) ranges (66\%) - Sambucus nigra, Rosa canina, Salix fragilis, Papaver rhoeas, Syringa vulgaris, Brassica campestris, Armoracia rusticana, Onobrychis viciifolia, Lonicera tatarica, Ornithogalum umbellatum, Aquilegia vulgaris, Lupinus polyphyllus and Cerastium tomentosum, and species with distribution range falling into the Holarctic moderate (sub-meridional, temperate) zone - (Saponaria officinalis, Oxalis stricta, Reynoutria japonica, Grossularia reclinata, Hesperis matronalis, Malus domestica, Veronica filiformis, Sambucus racemosa, Fragaria moschata, Lonicera caprifolium, Sedum sexangulare, Euphorbia cyparissias, Trifolium hybridum, Amelanchier spicata and Crataegus alemanniensis var. alemanniensis). Only one of the escaped species - Impatiens glandulifera have a panzonal distribution range (Fig. 1).

Significant differences were found between adventive species and escaped species in the spectrum of sectorial ranges (Fig. 2). Among the adventive species there were many cosmopolitan species, which are tolerant (indifferent) against the variation of air temperatures and moisture. However, the escaped species with distribution ranges in Holarctic zones are predominantly sub-oceanic. In the Lake Engure Nature Park sandy substrates prevail, which intensifies the continentality of microclimate. Therefore, there are numerous adventive alien species (32\% of all alien flora in the nature park) with sub-continental (Acorus calamus, Asperugo procumbens, Buglossoides arvensis, Corispermum leptopterum and Rumex confertus) and continental (Atriplex hortensis and Sisymbrium loeselii) distribution ranges.

Distribution of alien plant species in the nature park. The highest richness of alien plant species in the nature park was found in disturbed, modified habits in dynamic successional stages, such as roadsides, abandoned homesteads and arable lands and gardens. In the nature park, 53\% $(\mathrm{n}=35)$ of the alien species recorded was found on roadsides. Roadsides are rich both in adventive species (64\% of all recorded alien species) and in escaped species (48\% of all recorded alien species) (Table 1).

The second alien-richest habitat type was abandoned and extensively managed homesteads and their surroundings, which harboured $33 \%(n=22)$ of the total number of recorded alien species. Arable lands and gardens contained

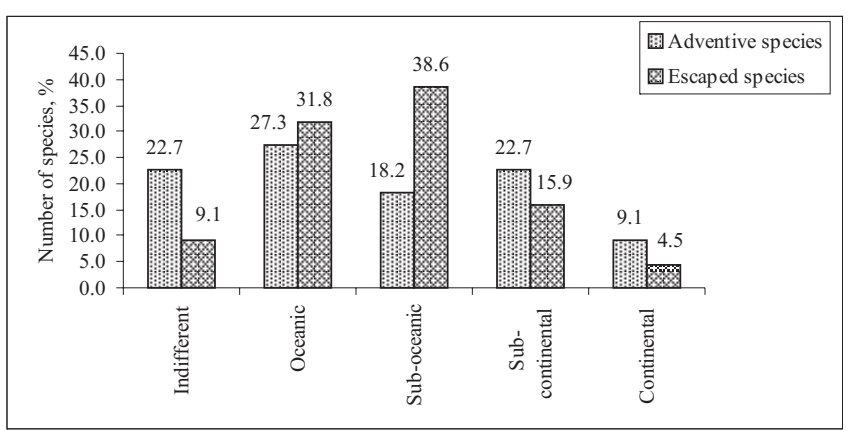

Fig. 2. Sectorial distribution ranges of alien flora in the nature park.

$27 \%(\mathrm{n}=18)$ of the recorded alien species. In total, $82 \%$ of the recorded adventive species and $73 \%$ of the recorded escaped species occurred on roadsides, homesteads and arable lands and gardens. Species such as the adventive Amaranthus retroflexus, Asperugo procumbens, Elscholtzia ciliata, Erucastrum gallicum, Galinsoga parviflora, G. quadriradiata, Carduus nutans, Hyosciamus niger, Lepidotheca suaveolens, and the escaped species Matricaria recutita, Mentha x pipertita, Onobrychis vicifolia, Ornithogalum umbellatum, Polemonium caerulea, Reynoutria japonica, Brassica campestris, Euphorbia cyparissias, Myosotis sylvatica, Veronica filiformis, Vicia sativa and Impatiens glandulifera were found only in human-modified, disturbed sites.

Coastal habitats (dunes, coastal marshes and muddy beaches) are among the alien-richest habitats. The narrow coastal zone harbours a surprisingly high number of escaped species (36\%). Evidently, the alien species spread out of the neighbouring gardens of coastal villages (Bērzciems, Mērsrags, Abragciems, Engure), establishing in the nearby coastal habitats. Most probably, the intensive use of the coastal zone for recreational purposes promotes the spread of propagules and invasion of numerous species. Escaped species found only in coastal habitats were Rosa acicularis, Salix x rubens and Sambucus nigra.

In Lake Engure and other shallow standing or slow-flowing freshwater bodies (drainage ditches, margins of ditches) few adventive species were recorded: Acorus calamus, Elodea canadensis, Epilobium adenocaulon and E. rubescens. In freshwater habitats only one escaped species - Zizania aquatica was found, which was intentionally introduced in the Lake Engure in 1951 (Spuris, 1953; 1955; Кристкалне, 1959), where the species successfully established, though not spreading over large areas. presently, established stands of $Z$. aquatica are known in the west part of the lake only (Gavrilova et al., 2005).

In forest habitats (dry pine woodlands, mixed deciduous-spruce forests, forest roads and tracks, forest glades, willow scrublands) mainly escaped species were recorded: Crataegus alemanniensis var. alemanniensis, Lonicera caprifolia, L. tatarica, Swida alba, Aster salignus, and Sedum album. Two adventive species - Juncus tenuis and 
Table 1

FREQUENCY OF ALIEN PLANT SPECIES IN THE LAKE ENGURE NATURE PARK

\begin{tabular}{|c|c|c|c|c|}
\hline \multirow[t]{3}{*}{ Species } & \multicolumn{4}{|c|}{ Spatial units } \\
\hline & \multicolumn{2}{|c|}{$\begin{array}{c}0.25 \mathrm{~km}^{2} \text { grid, } \\
\mathrm{n}=594\end{array}$} & \multicolumn{2}{|c|}{$\begin{array}{c}\text { Habitat types, } \\
\mathrm{n}=26\end{array}$} \\
\hline & number & $\%$ & number & $\%$ \\
\hline 1 & 2 & 3 & 4 & 5 \\
\hline \multicolumn{5}{|c|}{ Adventive species } \\
\hline Conyza canadensis (L.) Cronquist & 100 & 16.8 & 7 & 26.9 \\
\hline Lepidotheca suaveolens (Pursh) Nutt. & 60 & 10.1 & 3 & 11.5 \\
\hline Acorus calamus $\mathrm{L}$. & 35 & 5.9 & 3 & 11.5 \\
\hline Elodea canadensis Michx. & 34 & 5.7 & 3 & 11.5 \\
\hline Epilobium adenocaulon Hausskn. & 16 & 2.7 & 4 & 15.4 \\
\hline Galinsoga quadriradiata Ruiz et Pav. & 14 & 2.4 & 3 & 11.5 \\
\hline Rumex confertus Willd. & 13 & 2.2 & 3 & 11.5 \\
\hline Asperugo procumbens L. & 6 & 1.0 & 2 & 7.7 \\
\hline Corispermum leptopterum (Asch.) Iljin & 6 & 1.0 & 3 & 11.5 \\
\hline Juncus tenuis Willd. & 6 & 1.0 & 1 & 3.8 \\
\hline Amaranthus retroflexus $\mathrm{L}$. & 5 & 0.8 & 2 & 7.7 \\
\hline $\begin{array}{l}\text { Erucastrum gallicum (Willd.) O. E. } \\
\text { Schulz }\end{array}$ & 5 & 0.8 & 2 & 7.7 \\
\hline Galinsoga parviflora Cav. & 5 & 0.8 & 2 & 7.7 \\
\hline Sisymbrium loeselii $\mathrm{L}$. & 5 & 0.8 & 2 & 7.7 \\
\hline Buglossoides arvensis (L.) I. M. Johnst. & 3 & 0.5 & 2 & 7.7 \\
\hline Diplotaxis muralis (L.) DC. & 3 & 0.5 & 1 & 3.8 \\
\hline Elsholtzia ciliata (Thunb.) Hyl. & 3 & 0.5 & 2 & 7.7 \\
\hline Hyoscyamus niger $\mathrm{L}$. & 3 & 0.5 & 1 & 3.8 \\
\hline Atriplex hortensis L. & 2 & 0.3 & 2 & 7.7 \\
\hline Bunias orientalis L. & 2 & 0.3 & 3 & 11.5 \\
\hline Carduus nutans L. & 1 & 0.2 & 1 & 3.8 \\
\hline Epilobium rubescens Rydb. & 1 & 0.2 & 2 & 7.7 \\
\hline \multicolumn{5}{|c|}{ Escaped species } \\
\hline Salix fragilis L. & 63 & 10.6 & 3 & 11.5 \\
\hline Artemisia absinthium L. & 53 & 8.9 & 5 & 19.2 \\
\hline Ribes rubrum L. & 38 & 6.4 & 3 & 11.5 \\
\hline Saponaria officinalis L. & 34 & 5.7 & 5 & 19.2 \\
\hline Trifolium hybridum $\mathrm{L}$. & 32 & 5.4 & 2 & 7.7 \\
\hline Amelanchier spicata (Lam.) K. Koch & 28 & 4.7 & 4 & 15.4 \\
\hline $\begin{array}{l}\text { Armoracia rusticana P. Gaertn., B. } \\
\text { Mey. et Scherb. }\end{array}$ & 22 & 3.7 & 4 & 15.4 \\
\hline Sambucus racemosa $\mathrm{L}$. & 17 & 2.9 & 3 & 11.5 \\
\hline
\end{tabular}

Conyza canadensis were found only on forest roads and tracks.

Alien species were not found in moist and humid natural and semi-natural habitats: bog woodlands, swampy black alder forests, tall sedge and Molinia grasslands, fens and transitional mores and in calcareous fen-grassland habitats. The only species found in the Schoenus ferrugineus community in a transitional successional stage was Aquilegia vulgaris.

The composition of alien flora is shown in two-dimensional PCA ordination graphs (Fig. 3, Fig. 4). In the nature park,

\begin{tabular}{|c|c|c|c|c|}
\hline 1 & 2 & 3 & 4 & 5 \\
\hline Brassica campestris $\mathrm{L}$. & 12 & 2.0 & 2 & 7.7 \\
\hline Impatiens parviflora $\mathrm{DC}$. & 11 & 1.9 & 2 & 7.7 \\
\hline Vicia sativa $\mathrm{L}$. & 10 & 1.7 & 2 & 7.7 \\
\hline $\begin{array}{l}\text { Grossularia reclinata (L.) Mill. var. } \\
\text { uva-crispa }(\text { L.) Berger }\end{array}$ & 9 & 1.5 & 3 & 11.5 \\
\hline Rosa canina $\mathrm{L}$. & 9 & 1.5 & 4 & 15.4 \\
\hline Aquilegia vulgaris $\mathrm{L}$. & 8 & 1.3 & 3 & 11.5 \\
\hline Euphorbia cyparissias L. & 7 & 1.2 & 2 & 7.7 \\
\hline Matricaria recutita $\mathrm{L}$. & 7 & 1.2 & 1 & 3.8 \\
\hline Impatiens glandulifera Royle & 6 & 1.0 & 3 & 11.5 \\
\hline Rosa rugosa Thunb. & 6 & 1.0 & 3 & 11.5 \\
\hline Malus domestica Borkh. & 5 & 0.8 & 4 & 15.4 \\
\hline Myosotis sylvatica Ehrh. ex Hoffm. & 5 & 0.8 & 2 & 7.7 \\
\hline Swida alba (L.) Opiz & 5 & 0.8 & 2 & 7.7 \\
\hline Cerastium tomentosum $\mathrm{L}$. & 4 & 0.7 & 3 & 11.5 \\
\hline Syringa vulgaris $\mathrm{L}$. & 4 & 0.7 & 2 & 7.7 \\
\hline Solidago canadensis $\mathrm{L}$. & 4 & 0.7 & 2 & 7.7 \\
\hline Fragaria moschata Duch. & 3 & 0.5 & 2 & 7.7 \\
\hline Lonicera caprifolium $\mathrm{L}$. & 3 & 0.5 & 2 & 7.7 \\
\hline Sambucus nigra L. & 3 & 0.5 & 1 & 3.8 \\
\hline Sedum sexangulare L. & 3 & 0.5 & 3 & 11.5 \\
\hline Veronica filiformis $\mathrm{Sm}$. & 3 & 0.5 & 2 & 7.7 \\
\hline Hesperis matronalis $\mathrm{L}$. & 2 & 0.3 & 2 & 7.7 \\
\hline Lonicera tatarica $\mathrm{L}$. & 2 & 0.3 & 1 & 3.8 \\
\hline Lupinus polyphyllos Lindl. & 2 & 0.3 & 1 & 3.8 \\
\hline Mentha $\times$ piperita $\mathrm{L}$. & 2 & 0.3 & 1 & 3.8 \\
\hline Reynoutria japonica Houtt. & 2 & 0.3 & 1 & 3.8 \\
\hline Zizania aquatica $\mathrm{L}$. & 2 & 0.3 & 1 & 3.8 \\
\hline Aronia prunifolia (Marshall) Rehder & 1 & 0.2 & 2 & 7.7 \\
\hline $\begin{array}{l}\text { Crataegus alemanniensis Cin. var. } \\
\text { alemanniensis }\end{array}$ & 1 & 0.2 & 1 & 3.8 \\
\hline Onobrychis viciifolia Scop. & 1 & 0.2 & 1 & 3.8 \\
\hline Ornithogalum umbellatum $\mathrm{L}$. & 1 & 0.2 & 1 & 3.8 \\
\hline Oxalis stricta $\mathrm{L}$. & 1 & 0.2 & 2 & 7.7 \\
\hline Papaver rhoeas L. & 1 & 0.2 & 2 & 7.7 \\
\hline Polemonium caeruleum $\mathrm{L}$. & 1 & 0.2 & 1 & 3.8 \\
\hline Rosa acicularis Lindl. & 1 & 0.2 & 1 & 3.8 \\
\hline Salix $\times$ rubens Schrank & 1 & 0.2 & 1 & 3.8 \\
\hline Sedum album $\mathrm{L}$. & 1 & 0.2 & 1 & 3.8 \\
\hline Aster salignus Willd. & 1 & 0.2 & 1 & 7.7 \\
\hline
\end{tabular}

roadsides with gravely substrate (habitat 22 in Appendix 3) harbour numerous alien species and form a rather compact group in the ordination space. Arable lands, gardens and homesteads (habitats 20 and 21 in Appendix 3), and scrublands and freshwater habitats (habitats 8-12 and 16 in Appendix 3) also form compact groups in the ordination space.

Most of alien species have concentrated in the coastal villages along the Gulf of Riga (Mērsrags, Bērzciems, Abragciems, Engure villages), in the surroundings of the villages on the west coast of the Lake Engure (Kūḷciems, Krievragciems, Dzedri and Kipatciems villages), in areas 


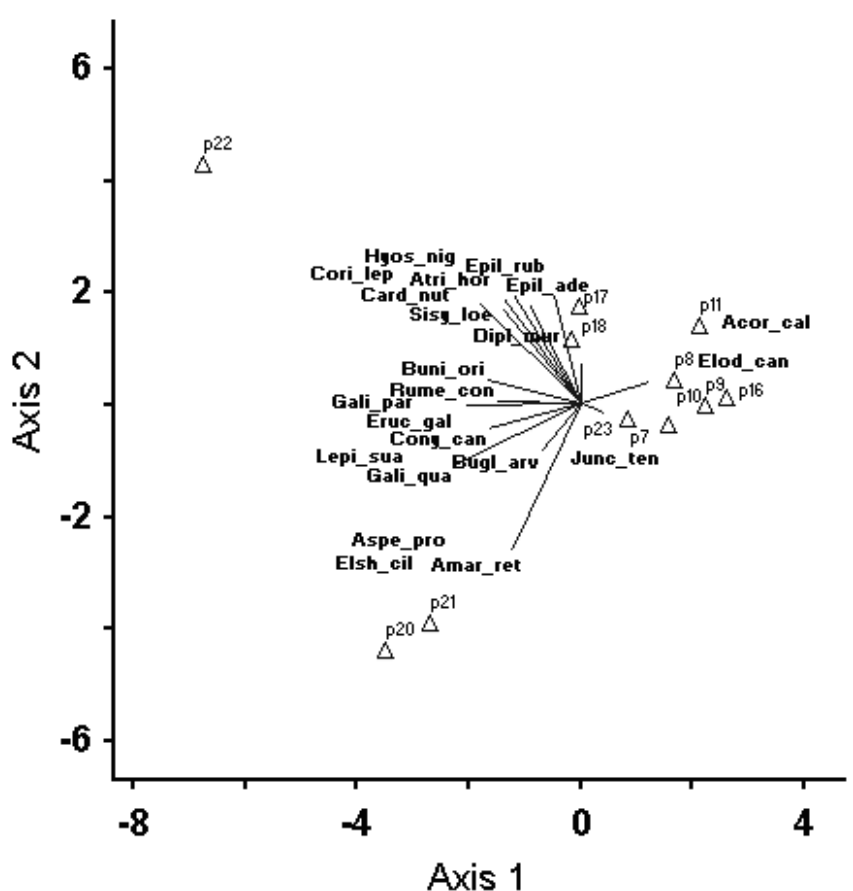

Fig. 3. Habitat ordination (PCA) for habitats of adventive species.

See species abbreviations in Appendix 1, numbered habitat types in Appendix 3 .

The first axis (eigenvalue 34.8\%) differentiates freshwater habitats and transformed habitats (roadsides, arable lands, homesteads). The highest species loadings were found for Acorus calamus 0.174 , Elodea canadensis 0.174, Galinsoga quadriradiata -0.325 , Lepidotheca suaveolens -0.325 , Galinsoga parviflora -0.299 . The second axis (eigenvalue $22.5 \%$ ) differentiates transformed habitats (roadsides, arable lands, homesteads). The highest species loadings were found for Epiloboium adenocaulon 0.278, Atriplex hortensis 0.270, Amaranthus retroflexus -0.376, Asperugo procumbens -0.376 , Elscholzia ciliata -0.376 .

dominated by agricultural lands (arable lands, gardens, grasslands, pastures etc.), in the surroundings of human settlements and in the vicinity of roads, sea coast and streams discharging into Lake Engure (Dzedrupe and Dursupe) (Figs. 5, 6).

No significant differences were found in the distribution patterns of adventive and escaped species (Figs. 5, 6). Species of both groups are concentrated in the surroundings of human settlements and roadsides, which are suitable habitats for most of the alien species. Human settlements are the major donor areas of alien species, and therefore surrounding suitable habitats are often invaded by alien plant species. Some roads play a crucial role in the spread of alien species. We suggest that the formation of floristic diversity in the nature park has been promoted by successful long-term migration, particularly along the sea coast and streams, while the short-term spread of alien plants occurs mainly along human-created pathways (Fig. 7).

\section{DISCUSSION}

Most of the alien species in the nature park are rather common in Latvia, but some are fairly rare or have uneven distribution patterns, e.g., Buglossoides arvensis, Diplotaxis muralis, Elsholtzia ciliata, Hyoscyamus niger, Onobrychis viciifolia, and Carduus nutans. Numerous alien species are well-naturalised common invaders not only in the nature park, but also throughout the country. For example, Bunias orientalis, Rumex confertus, Solidago canadensis, Galinsoga parviflora, G. quadriradiata, Amelachier spicata, Saponaria officinalis, Impatiens glandulifera, I. parviflora, Lupinus polyphyllus, and Sambucus racemosa have high invasion ability (e.g., Priede, 2009). Historical factors are particular important in explaining the current composition of alien flora. Numerous rare adventive species have established due to coincidence of accidental factors, e.g., unintentional transportation of propagules, and do not spread extensively, while many invasive escaped species, such as Amelanchier spicata, Aronia prunifolia, Solidago

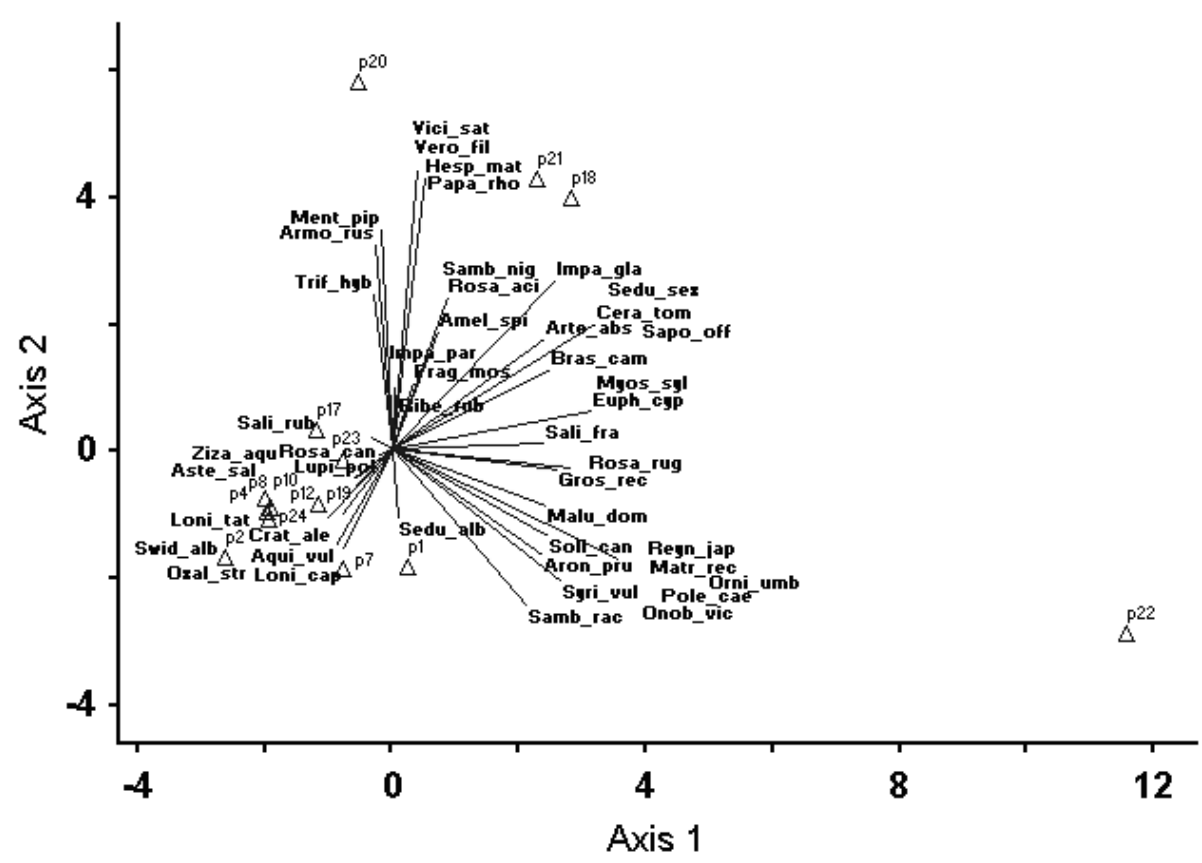

Fig. 4. Habitat ordination (PCA) for habitats of escaped species.

See species abbreviations in Appendix 2, numbered habitat types in Appendix 3.

The first axis (eigenvalue $25.7 \%$ ) differentiates roadside habitats. The highest species loadings were found for Matricaria recutita 0.261, Onobrychis viciifolia 0.261 , Ornithogalum umbellatum -0.261, Oxalis stricta -0.077, Lonicera caprifolia -0.057 , Lonicera tatarica 0.046 . The second axis (eigenvalue 13.2\%) differentiates transformed non-wooded and woodland habitats; the highest species loadings were found for Vicia sativa 0.323, Papaver rhoeas 0.314, Hesperis matronalis 0.314, Sambucus racemosa -0.183 , Syringa vulgaris -0.183 . 


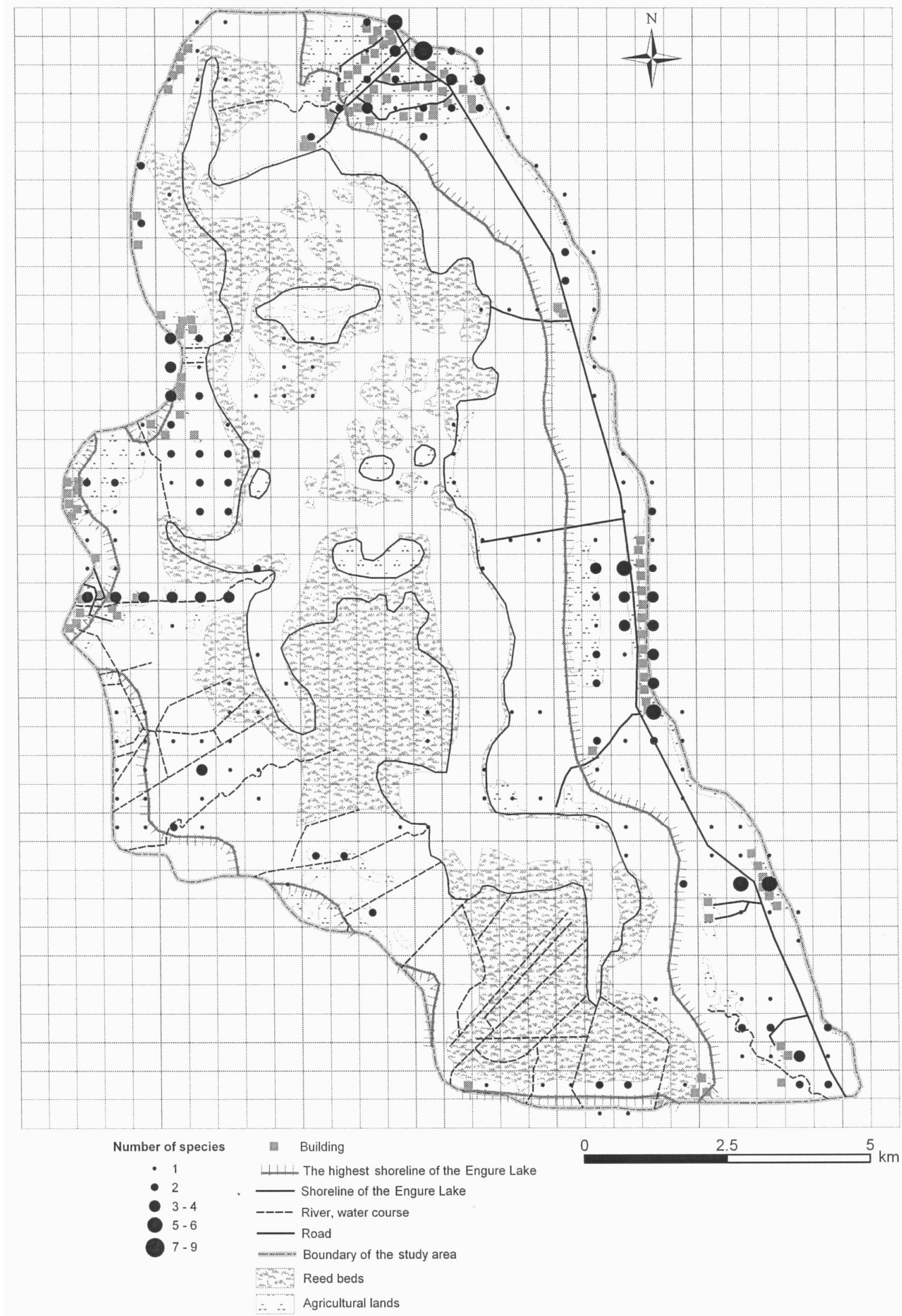

Fig. 5. Number of adventive species per grid unit in the Lake Engure $\mathrm{Na}$ ture Park.
Canadensis and Impatiens glandulifera are traditionally cultivated in gardens and have rapidly spread by wind and bird dispersal, especially along landscape corridors. Vicinity of suitable habitats near cultivation sites and uncontrolled disposal of garden waste have largely contributed to the formation of today's composition of alien flora in the nature park.

Over the last 20 years, four invasive species have newly established in the nature park: Aster salignus, Solidago canadensis, Lupinus polyphyllus and Swida sericea, and some invasive species have extended their distribution, e.g.,
Aronia prunifolia and Amelanchier spicata are intensively spreading in coastal grasslands and wooded dunes in the coastal areas. Presence of donor areas, habitat suitability and presence of migration corridors seem to be the crucial factors promoting the spread of alien plant species.

Presence and distribution patterns of alien species, particularly regarding invasive aliens, are suitable indicators of human impact. Overall, the distribution patterns of alien species are similar to other regions in Latvia, e.g., the Abava River Valley and Kemeri National Park (Priede, 2009a; 


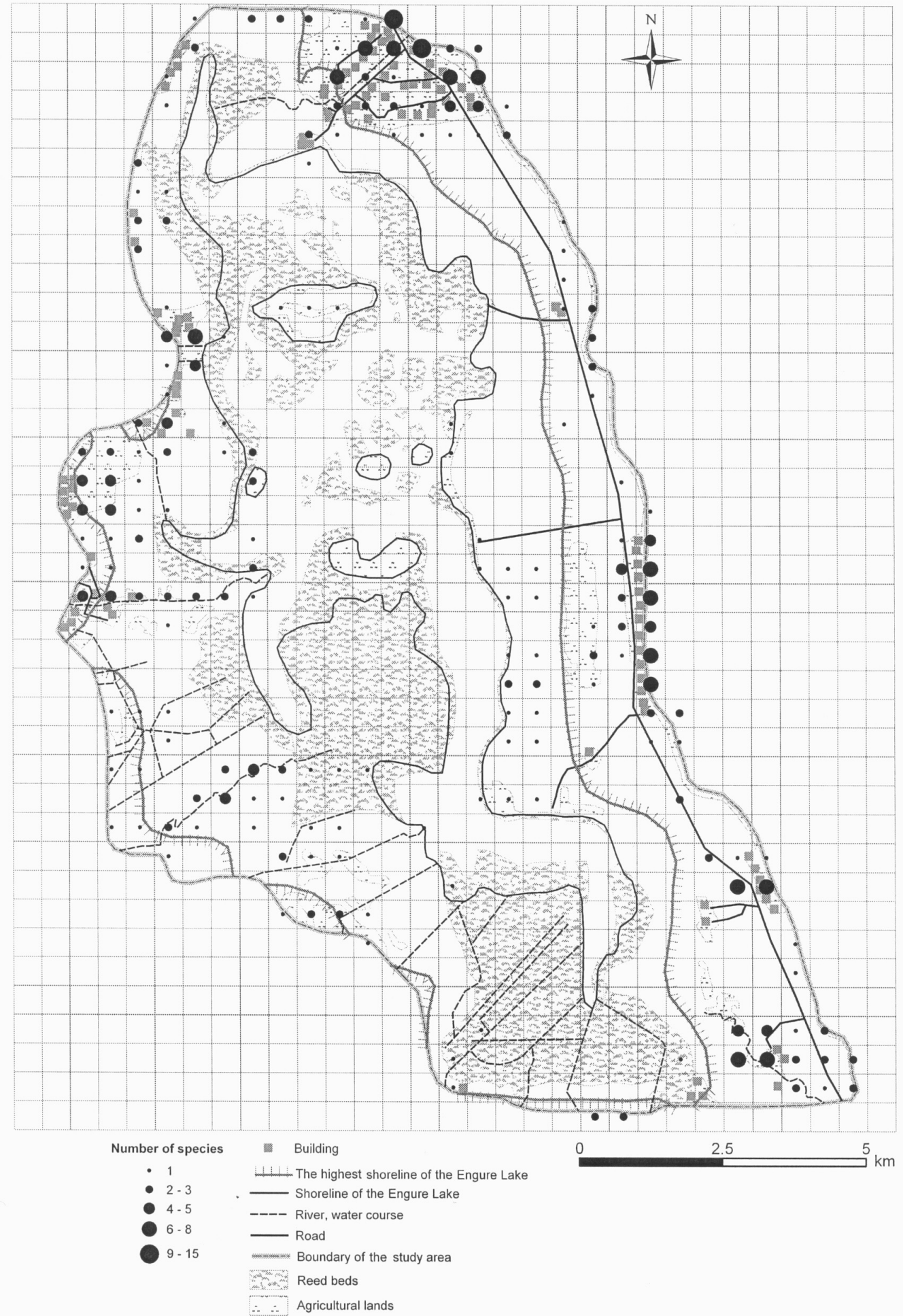

Fig. 6. Number of escaped species per grid unit in the Lake Engure Nature Park. 2009b), where the majority of alien plant species are concentrated in urban areas, and near roads, agricultural lands, and sub-urban forests. In comparison to the overall situation in Latvia, the Lake Engure Nature Park is relatively little affected by human-caused habitat modifications, it is rich in native species and is less affected by plant invasions. Since fragmented and urbanised landscapes lie almost only in the marginal areas of the nature park, large areas of natural and semi-natural habitats and high naturalness of vegetation play perhaps a significant role as natural barriers hindering alien invasions in the nature park.

\section{ACKNOWLEDGEMENTS}

We are thankful to Ilmārs Krampis for the interpretation of the CORINE Land Cover 2006 data. The study was supported by the Latvian Council of Sciences within the project No.10.0004. 


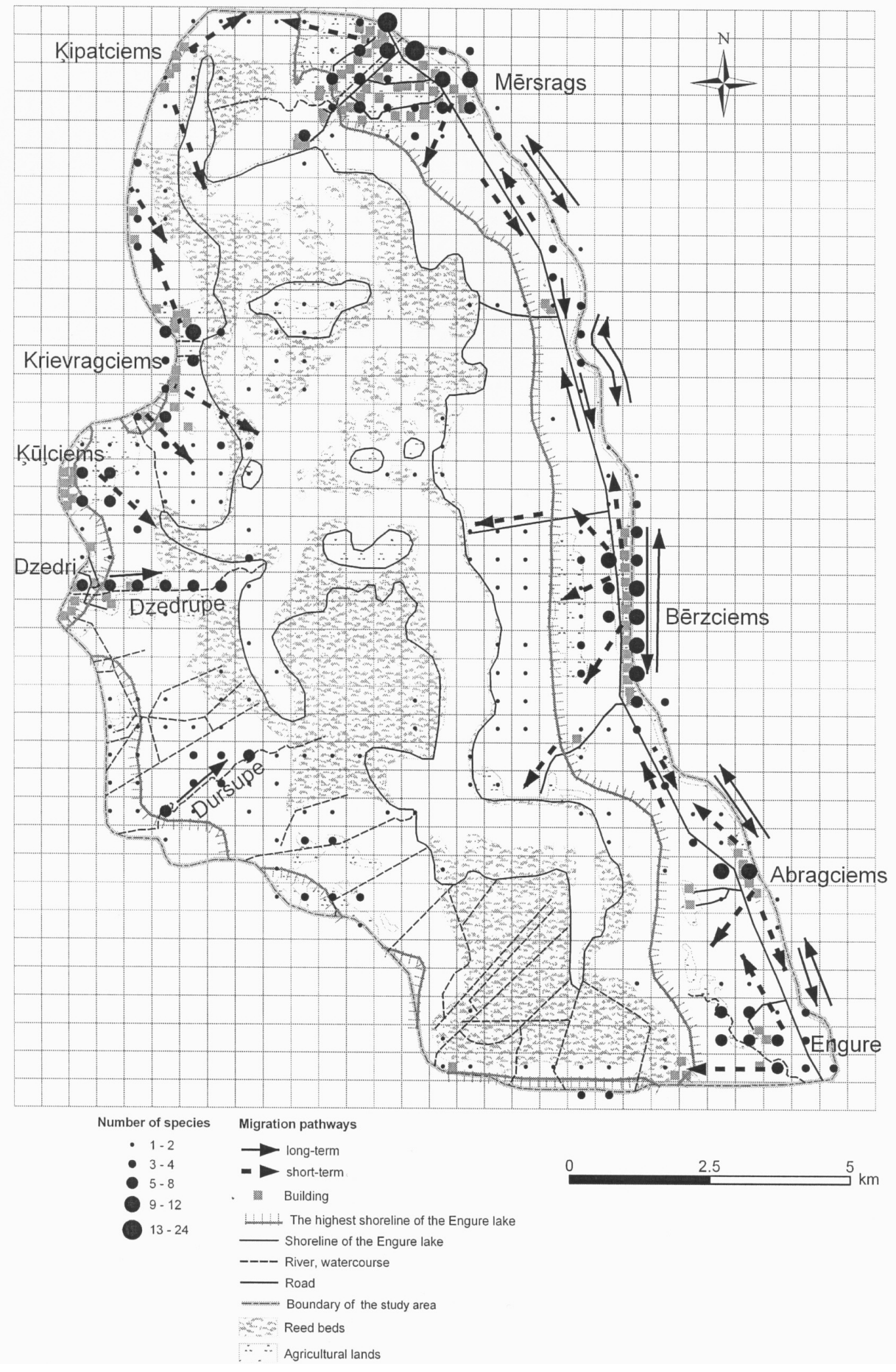

Fig. 7. Density of alien species per grid unit and their migration pathways in the Lake Engure Nature Park.

APPENDIX 1. Adventive species (abbreviations in brackets)

Acorus calamus $\mathrm{L}$. (Acor_calam)

Amaranthus retroflexus L. (Amar_retr)

Asperugo procumbens L. (Aspe_proc)

Atriplex hortensis L. (Atri_proc)

Buglossoides arvensis (L.) I. M. Johnst. (Bugl_arve)

Bunias orientalis L. (Buni_orie)

Carduus nutans L. (Card nuta)

Conyza canadensis (L.) Cronquist (Cony_cana)

Corispermum leptopterum (Asch.) Iljin (Cori_lept)

Diplotaxis muralis (L.) DC. (Dipl_mura)

Elodea canadensis Michx. (Elod_cana)
Elsholtzia ciliata (Thunb.) Hyl. (Elsc_cili)

Epilobium adenocaulon Hausskn. (Epil_aden)

Epilobium rubescens Rydb. (Epil_rube)

Erucastrum gallicum (Willd.) O. E. Schulz (Eruc_gall)

Galinsoga parviflora Cav. (Gali_parv)

Galinsoga quadriradiata Ruiz et Pav. (Galin_quad)

Hyoscyamus niger L. (Hyos_nige)

Juncus tenuis Willd. (Junc_tenu)

Lepidotheca suaveolens Pursh) Nutt. (Lepi_suav)

Rumex confertus Willd. (Rume_conf)

Sisymbrium loeselii L. (Sisy loes) 
APPENDIX 2. Escaped species (abbreviations in brackets)

Amelanchier spicata (Lam.) K. Koch (Amel_spic)

Aquilegia vulgaris L. (Aqui_vulg)

Armoracia rusticana P. Gaertn., B. Mey. et Scherb. (Armo_rust)

Aronia prunifolia (Marshall) Rehder (Aron_prun)

Artemisia absinthium L. (Arte_absi)

Aster salignus Willd. (Aste_Sali)

Brassica campestris L. (Bras_camp)

Cerastium tomentosum $\mathrm{L}$. (Cera_tome)

Crataegus alemanniensis Cin. var. alemanniensis (Crat_alam)

Euphorbia cyparissias L. (Euph_cypa)

Fragaria moschata Duch. (Frag_mosc)

Grossularia reclinata (L.) Mill. var. uva-crispa (L.) Berger (Gros_uva)

Hesperis matronalis L. (Hesp_matr)

Impatiens glandulifera Royle (Impa_glan)

Impatiens parviflora DC. (Impa_parv)

Lonicera caprifolium L. (Loni_capr)

Lonicera tatarica $\mathrm{L}$. (Loni_tat)

Lupinus polyphyllus Lindl. (Lupi_poly)

Malus domestica Borkh. (Malu_dome)

Matricaria recutita L. (Matr_recu)

Mentha $\times$ piperita L. (Ment_pipe)

Myosotis sylvatica Ehrh. ex Hoffm. (Myos_sylv)

Onobrychis viciifolia Scop. (Onob_vici)

Ornithogalum umbellatum L. (Orni_umbe)

Oxalis stricta L. (Oxal_stri)

Papaver rhoeas L. (Papa_rhoe)

Polemonium caeruleum L. (Pole_caer)

Ribes rubrum L. (Ribe_rubr)

Rosa acicularis Lindl. (Rosa_acic)

Rosa canina L. (Rosa_cani)

Rosa rugosa Thunb. (Rosa_rugo)

Reynoutria japonica Houtt. (Reyn_japo)

Salix fragilis L. (Sali_frag)

Salix $\times$ rubens Schrank (Sali_rube)

Sambucus nigra L. (Samb_nigr)

Sambucus racemosa L. (Samb_race)

Saponaria officinalis L. (Sapo_offi)

Sedum album L. (Sedu_albu)

Sedum sexangulare L. (Sedu_sexa)

Solidago canadensis L. (Soli_cana)

Swida alba (L.) Opiz (Swid_alba)

Syringa vulgaris L. (Syri_vulg)

Trifolium hybridum L. (Trif_hybr)

Veronica filiformis Sm. (Vero_fili)

Vicia sativa $\mathrm{L}$. (Vici_sati)

Zizania aquatica L. (Zizi_aqua)

\section{APPENDIX 3. Habitats}

Woodland habitats

1. Dry pine woodlands (Dicrano-Pinion)

2. Mixed deciduous-spruce forests (Alno-Ulmion)

3. Bog woodlands (Ledo-Pinion)

4. Calciphilous sparse pine woodlands (Sesleria-Pinus com., Schoenus-Pinus com.)

5. Black alder swampy forests (Alnion glutinosae)

6. Forest clearings (Dicrano-Pinion)

7. Forests roads, tracks, glades

(Convolvulo-Agropyrion)

Scrublands

8. Riparian willow scrub (Salicion albae, Salicion cinerea)

Freshwater habitats

9. Vegetation of submersed and free-floating aquatic macrophytes (Potamion)

10. Emerged freshwater vegetation and wet depressions (Lemnetalia, Sphagno-Utricularion)

11. Streams and drainage ditches

(Glycerio-Sparganion, Ranunculion fluitantis)

12. Reed beds (Phragmition)

Mires and fens

13. Fens and transitional mires (Caricion lasiocarpae)

14. Calcareous fens (Caricion davallianae)

15. Calcareous fens with Schoenus ferrugineus (Schoenus ferrugineus com.)

Vegetation of brack-

ish waters and 16. Emerged vegetation in brackish coastal waters coastal grasslands (Potametea, Ruppietea maritimae)

17. Overgrowing beaches (Phragmition,

Bolboschenion)

18. Herbaceous beach communities

(Agropyro-Honkenion, Ammophilion arenariae)

19. Coastal grasslands (Armerion maritimae)

Disturbed habitats

20. Arable lands and gardens (Aperion spica-venti, Fumario-Euphorbion)

21. Abandoned homesteads, orchards and yards (Polygonion avicularis, Aegopodion)

22. Roadsides and waste grounds (Sisymbrion, Arction lappae)

Grasslands

23. Mesophile pastures and humid euthropic grasslands (Cynosurion, Calthion)

24. Hay meadows (Arrhenatherion, Alopecurion)

25. Floodplain hay meadows and tall sedge communities (Magnocaricion, Caricion nigrae)

26. Molinia meadows and Myrica gale scrubs (Molinion, Myricetum gale) 


\section{REFERENCES}

Anonymous (2010). Corine Land Cover 2006 (CLC2006) $100 \mathrm{~m}$ - version 13 (02/2010). European Environment Agency. Available at: http://www.eea.europa.eu.

Auniňš, A. (ed.) (2010). Eiropas Savienības aizsargājamie biotopi Latvijā. Noteikšanas rokasgrāmata [EU protected habitats in Latvia. A key]. Rīga: Latvijas Dabas fonds. 319 1pp. (in Latvian).

Auniņš, A., Zviedre, E., Brūmelis, G. (2000). Preliminary results of remote sensing based vegetation mapping of Lake Engures (Engure), Latvia. Proc. Latvian Acad. Sci., 54(5/6), 170-176.

Birzvalks, A. (1938). Cīnas un nemieri ap Engures ezeru pagājušā gadsimta otrā pusē [Fights and unrest in the surroundings of the Lake Engure in the second half of the last century]. Izglìtības Ministrijas Mēnešraksts, 2, 176, 187 (in Latvian).

Gavrilova, G̦. (1990). Sargājams dabas objekts Engurē [A nature area subjected to protection in Engure]. Zinātne un Tehnika, 2, 14-16 (in Latvian).

Gavrilova, G. (1999). Engures ezera dabas parka ūdensaugu flora [Aquatic flora in the Lake Engure]. In: Zeme. Daba. Cilvēks. Latvijas Universitātes 57. zinātniskā konference (43.-45. 1pp.). Kḷaviṇš, M. (ed.). Rīga: Latvijas Universitāte (in Latvian).

Gavrilova, G., Šulcs, V. (1999). Latvijas vaskulāro augu flora. Taksonu saraksts [Checklist of Latvia's Vascular Plant Flora]. Rīga: Latvijas Akadēmiskā bibliotēka. 136 lpp.

Gavrilova, G., Baronina, V. (2000). Vascular plant flora of the Lake Engures (Engure) drainage basin, Latvia, and the coastal zone of the Gulf of Rìga. Proc. Latvian Acad. Sci., Section B, 54(5/6), 177-189.

Gavrilova, G., Krampis, I., Laiviňš, M. (2005). Engures ezera dabas parka floras atlants. Vaskulārie augi [Atlas of the vascular plant flora in the Lake Engure Nature Park]. Latvijas Veǵetācija, 10, 1-229 (in Latvian).

Kabucis, I., Račinska, I., Pozņaka, L. (2004). Engures ezera dabas parka dabas aizsardzības plāna ieviešana [Implementation of the Management of the Lake Engure Nature Park]. Rīga: Latvijas Dabas fonds. 16 lpp. (in Latvian).

Kupffer, K. (1925). Grundzüge der Pflanzengeographie des Ostbaltischen Gebietes. Abhandlungen des Herder-Instituts zu Riga, 1(6), I-V, 1-224.

Laime, B. (2000). Seashore plant communities of the Lake Engures (Engure) Nature Park, Latvia. Proc. Latvian Acad. Sci., Section B, 54(5/6), 190-196.

Laiviňš, M. (1998). Latvijas ziedaugu un paparžaugu sabiedrību augstākie sintaksoni [The highest syntaxons of the flowering plants and ferns in Latvia]. Latvijas purvu veǵetācijas klasifikācija un dinamika. Latvijas Universitātes Zinātniskie Raksti, 613, 7-22 (in Latvian)

Linkaitis, L., Rìts, J. (1972). Latvijas PSR dabas un pieminekḷ aizsardzība. [Protection of Nature and Cultural Monuments in the Latvian SSR]. Rīga: Liesma, 338 1pp. (in Latvian).

McCune, B., Grace, J.B. (2002). Analysis of Ecological Communities. MJM Publishers.
Mihelsons, H. (1960). Engures ezera putnu fauna [Bird fauna of the Lake Engure]. Latvijas putnu dzīve. Ornitologiski pettījumi (5.-43. 1pp.). Spuris Z. (ed.). 2. sēj. Rīga: LPSR ZA izdevniecība (in Latvian).

Pakalne, M. (1994). Zāḷ purvu un ezeru krastmalu retās fitocenozes Baltijas jūras krastā (Latvija, Piejūras zemiene). Disertācijas kopsavilkums [Rare rich fen and lakeside communities of the Baltic coast. Doctoral thesis: summary]. Rīga. 34 lpp. (in Latvian).

Priede, A. (2009a). Dynamics of non-native flora: Changes over the last decades in the valley of River Abava. Acta Universitatis Latviensis, 724, 89-108.

Priede, A. (2009b). Invazīvie neofíti Latvijas florā: izplatība un dinamika. Promocijas darbs [Invasive neophytes in the flora of Latvia: Distribution and dynamics. Doctoral thesis]. Rīga: Latvijas Universitāte, 125 lpp. (in Latvian).

Rasiņš, A. (1954). Latvijas PSR nezāḷ augḷi un sēklas [Fruits and Seeds of the Weeds in the Latvian SSR]. Riga: Latvijas Valsts izdevnieciba. 423 lpp. (in Latvian).

Rūsiṇa, S. (2007). Latvijas mezofìto un kserofīto zālāju daudzveidība un kontaktsabiedrības [Diversity and contact communities of mesophytic and xerophytic grasslands in Latvia]. Latvijas Vegetācija, 12, 1-366 (in Latvian).

Salmiņa, L. (2009). Limnogēno purvu veǵetācija Latvijā [Limnogenous mire vegetation of Latvia]. Latvijas Veǵetācija, 19, 1-181 (in Latvian).

Siliņš, A. (ed.) (1988). İpaši aizsargājamie dabas objekti Latvijas PSR teritorija $\bar{a}$ [Protected Nature Monuments in the Territory of the Latvian SSR]. Rīga: Avots. 101 lpp. (in Latvian).

Sončika, K. (2006). Engures ezera dabas parka vaskulāro augu floras daudzveidība un vides traucējumi. Bakalaura darbs [Diversity of vascular plant flora and environmental distrubances in the Lake Engure Nature Park. Bachelor's work]. Rīga: Latvijas Universitāte. 81 lpp. (in Latvian).

Spuris, Z. (1953). Par Latvijas PSR ezeru pētniecību un ezeru zivsaimniecības stāvokli un uzdevumiem [On the lake research and status of lake fisheries in the Latvian SSR]. Latvijas PSR Zinātñu Akadèmijas Vēstis, 2, 35-42 (in Latvian).

Spuris, Z. (1955). Jaunas ziņas par dažu augu izplatību Latvijas PSR [Notes on the distribution of some plants in the Latvian SSR]. Latvijas PSR Zinātņu Akadēmijas Vēstis, 9, 61-63 (in Latvian).

Vīksne, J. (1997). Engure - putnu ezers [Bird Lake Engure]. Rīga: Jāṇa sēta. 109 lpp. (in Latvian).

Кристкалне С. Х. (1959). Водяной рис (Zizania aquatica L.) в Латвийской CCP [Wild rice (Zizania aquatica L.) in the Latvian SSR]. Ботанический журнал 44(2), 209-211 (in Russian).

Спурис 3. (1960). Лимнологическая характеристика озера Энгурес [Limnological characteristics of Lake Engure]. Я.Я. Лусис (ред.) Рыбное хозяйство внутрееных водоемов Латвийской ССР. Т. 1 (c. 167-198). Рига: Изд-во АН Латвийской CCP (in Russian).

Received 9 November 2011

\section{SVEŠZEMJU AUGU FLORA ENGURES EZERA DABAS PARKĀ}

Rakstā apskatìta dabas parka „Engures ezers” — vienas no sugām bagātākajām teritorijām Latvijā — vaskulāro svešzemju (allohtono) augu flora. Analīze balstīta uz 1983.-1989. gadā un 2010. gadā īstenotās sugu inventarizācijas datiem. Konstatētas 68 svešzemju sugu sugas, kas veido 7.6\% no dabas parka floras. Salīdzinot abus inventarizācijas periodus, sugu skaits palielinājies par četrām. Svešzemju vaskulāro augu sugu kompleksu veido 22 adventīiās un 46 dārzbēgḷ sugas. Lielākā daḷ svešzemju sugu un to atradṇu koncentrētas piekrastes ciemos un citu apdzīvotu vietu apkārtnē, ceḷmalās, piekrastes kāpās un pie Engures ezerā ietekošajām upēm, lielākoties cilvēka darbības pārveidotos biotopos. Savukārt dabiskos un pusdabiskos biotopos šo sugu ir maz vai vispār nav. Salīdzinot ar situāciju Latvijā kopumā, dabas parks ir svešzemju sugu invāziju maz ietekmēts, domājams, lielā dabisku un mazietekmētu biotopu īpatsvara, kā arī maz pārveidotas dabiskās veğetācijas dēl — tā kalpo kā dabiska barjera, kavējot plašas svešzemju augu invāzijas. 